agriTECH, 40 (1) 2020, 39-47

\title{
Pemurnian Produk Mono-Diasilgliserol (MDAG) Hasil Gliserolisis Kimia dengan Metode Demulsifikasi Krim
}

\author{
Purification of Mono-Diacylglycerol (MDAG) Product by the Glycerolysis Process using Cream \\ Demulsification Method
}

\author{
Satiti Kawuri Putri ${ }^{1}$, Purwiyatno Hariyadi1 ${ }^{12^{*}}$, Mursalin ${ }^{3}$, Nuri Andarwulan ${ }^{1,2}$ \\ ${ }^{1}$ Departemen Ilmu dan Teknologi Pangan, Fakultas Teknologi Pertanian, Institut Pertanian Bogor, \\ Jl. Lingkar Akademik Kampus IPB, Dramaga Bogor 16680, Indonesia \\ ${ }^{2}$ Southeast Asian Food and Agricultural Science and Technology (SEAFAST) Center, Institut Pertanian Bogor, \\ Dramaga Bogor 16680, Indonesia \\ ${ }^{3}$ Fakultas Teknologi Pertanian, Universitas Jambi, \\ Jl. Tribrata, Desa Pondok Meja Km. 11, Mestong Jambi 36364, Indonesia \\ *Penulis korespondensi: Purwiyatno Hariyadi, Email: phariyadi@yahoo.com
}

Tanggal submisi: 15 Agustus 2019; Tanggal penerimaan: 16 Oktober 2019

\begin{abstract}
ABSTRAK
Demulsifikasi krim merupakan salah satu cara pemurnian untuk memisahkan residu gliserol yang terikat secara emulsi pada produk Mono-Diasilgliserol (MDAG). Metode ini dapat digunakan untuk memecah sistem emulsi dengan penambahan larutan elektrolit. Penelitian ini bertujuan untuk membandingkan kalsium klorida dan kalsium nitrat sebagai larutan elektrolit pada metode demulsifikasi krim dalam memurnikan MDAG. MDAG yang digunakan adalah Fully Hydrogenated Palm Kernel Oil (FHPKO) hasil gliserolisis kimia. Hasil penelitian menunjukkan pemurnian MDAG dengan metode demulsifikasi krim pada perlakuan elektrolit kalsium nitrat maupun elektrolit kalsium klorida memiliki hasil yang tidak berbeda berdasarkan Uji-T $(p>0,05)$. Perlakuan penambahan elektrolit kalsium nitrat pada pemurnian MDAG dengan metode demulsifikasi krim dapat menurunkan kadar gliserol dari $11,69 \pm 0,88 \%$ menjadi $0,57 \pm 0,07 \%$ dengan karakteristik kadar asam lemak bebas (ALB) $8,51 \pm 0,94 \%$, kadar monoasilgliserol (MAG) $31,53 \pm 3,27 \%$, kadar diasilgliserol (DAG) $19,46 \pm 0,52 \%$, kadar triasilgliserol (TAG) 39,93 $\pm 4,66 \%$ dan rendemen $81,00 \pm 3,61 \%$. Perlakuan penambahan kalsium klorida dapat menurunkan kadar gliserol dari $11,69 \pm 0,88 \%$ menjadi $0,64 \pm 0,06 \%$ dengan karakteristik kadar ALB $(8,91 \pm 0,71 \%)$, kadar MAG $(29,79 \pm 1,97 \%)$, kadar DAG $(19,16 \pm 0,53 \%)$, kadar TAG $(41,49 \pm 3,24 \%)$ dan rendemen $(80,00 \pm 4,00 \%)$. Berdasarkan hasil penelitian, kalsium nitrat dapat digunakan untuk menggantikan kalsium klorida sebagai larutan elektrolit pada metode demulsifikasi krim terutama dalam menurunkan residu gliserol.
\end{abstract}

Kata kunci: Demulsifikasi krim; mono-diasilgliserol; pemurnian

\begin{abstract}
Cream demulsification is one of the purification method for separating the glycerol residue contained as emulsion with MDAG's product. This method could be used to break emulsion system by adding electrolyte solution. This research aims to compare the performance of calcium chloride and calcium nitrate as electrolyte solution that is used in the process of cream demulsification. MDAG used was Fully Hydrogenated Palm Kernel Oil (FHPKO) from glycerolysis process. Based on student t-test, there was no significant difference $(p>0,05)$ detected between the products of cream demulsification method using calcium nitrate and calcium chloride as electrolyte solution. It was discovered that calcium nitrate reduced residual glycerol from $11,69 \pm 0.88 \%$ to $0,57 \pm 0,07 \%$; with characteristics

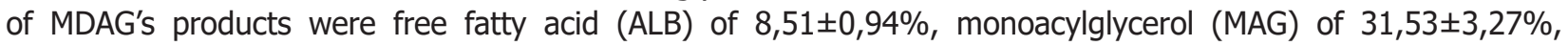

DOI: http://doi.org/10.22146/agritech.48779

ISSN 0216-0455 (Print), ISSN 2527-3825 (Online) 
diacylglycerol (DAG) of $19,46 \pm 0,52 \%$, triacylglycerol (TAG) of $39,93 \pm 4,66 \%$ and yield of $81,00 \pm 3,61 \%$. respectively. In other hand, calcium chloride reduced residual glycerol from $11,69 \pm 0,88 \%$ to $0,64 \pm 0,06 \%$; with characteristics of MDAG's products were ALB of $8,91 \pm 0,71 \%$, MAG of $9,79 \pm 1,97 \%$, DAG of $19,16 \pm 0,53 \%$, TAG of $41,49 \pm 3,24 \%$ and yield of $80,00 \pm 4,00 \%$, respectively. Therefore, calcium nitrate can be to replace calcium chloride as electrolyte solution in cream demulsification method, especially in reducing the glycerol residue.

Keywords: Cream demulsification; mono-diacylglycerol; purification

\section{PENDAHULUAN}

Mono-diasilgliserol (MDAG) merupakan salah satu pengemulsi yang diperoleh dari hasil turunan minyak kelapa sawit dan minyak inti sawit. Penggunaan MDAG mewakili $75 \%$ sebagai pengemulsi secara keseluruhan pada industri makanan. MDAG digunakan pada pengolahan margarin, cokelat, roti, biskuit, kue-kue kering dan es krim (Moonen dan Bas, 2015). Menurut Mardaweni dkk. (2017), MDAG dapat digunakan sebagai pengemulsi karena memiliki molekul yang terdiri dari bagian hidrofilik pada gugus $\mathrm{OH}$ dan bagian lipofilik pada gugus ester asam lemak. MDAG merupakan pengemulsi water-in-oil (w/o) dengan karakteristik rentang nilai Hydrophilic-Lipophilic Balance (HLB) yaitu 2-5 (McClements, 2015), tidak memiliki bau dan rasa, tidak larut air pada suhu ruang dan memiliki kelarutan yang terbatas pada minyak, kecuali pada suhu tinggi (O'Brien, 2009).

MDAG dapat diproduksi secara kimia dengan metode gliserolisis menggunakan katalis alkali pada suhu tinggi sekitar $200-260{ }^{\circ} \mathrm{C}$ (Rarokar dkk., 2017) akan menghasilkan monogliserida, digliserida dan trigliserida serta fraksi gliserol yang tidak bereaksi. Penelitian mengenai produksi MDAG secara gliserolisis kimia telah banyak dilakukan, secara umum MDAG yang dihasilkan masih mengandung residu gliserol sebesar $16,61-19,04 \%$ dari bahan baku refined bleached deodorized palm oil (RBDPO) pada skala laboratorium (Rachmawati, 2017) dan 7,26-12,29\% dari bahan baku stearin skala pilot plant (50 kg) (Agustina, 2019). Hasil tersebut relatif tinggi karena batas maksimum kandungan gliserol yang diregulasikan oleh Uni Eropa pada produk MDAG adalah maksimal 7\%. Oleh sebab itu, diperlukan upaya pemurnian untuk memisahkan gliserol sebagai residu pada produk MDAG hasil gliserolisis kimia. Metode pemurnian MDAG dapat dilakukan dengan Short Path Distillation (SPD) (Rossi dkk., 2012; Zhang dkk., 2014), ekstraksi menggunakan pelarut (Rumondang dkk., 2016; Sanchez dkk., 2018), ekstraksi pelarut dan distilasi molekuler (Mardaweni dkk., 2017), saponifikasi dan ekstraksi pelarut (Setyaningsih dkk., 2016) dan demulsifikasi pembentukan krim (Mursalin dkk., 2017a; Mursalin dkk., 2017b).
Sanchez dkk. (2018) menyatakan bahwa pemurnian menggunakan metode distilasi molekuler memerlukan biaya yang besar. Alat ini sangat mahal dan sulit diaplikasikan secara luas (Mursalin dkk., 2017a). Ekstraksi menggunakan pelarut dalam memurnikan MDAG juga memiliki beberapa kendala yaitu adanya sisa pelarut di produk akhir (Mursalin dkk., 2017b), prosedur pengerjaan yang lama dan menurunkan rendemen (Sanchez dkk., 2018). Demulsifikasi krim menjadi metode baru dalam memurnikan MDAG yang lebih efisien dibandingkan dengan metode distilasi molekuler dan ekstraksi pelarut terutama dalam memisahkan residu gliserol. Gliserol terbentuk sebagai hasil samping reaksi gliserolisis (Mursalin dkk., 2017a) yang terikat secara emulsi pada gugus $\mathrm{OH}$ di dalam produk MDAG. Tingginya suhu selama proses gliserolisis dapat menyebabkan gliserol menjadi coklat gelap yang akan mempengaruhi warna pada produk MDAG (Laksana, 2016). Oleh sebab itu diperlukan upaya untuk memisahkan gliserol yang terikat pada produk MDAG dengan demulsifikasi atau pemecahan emulsi menjadi komponen penyusunnya yaitu dalam bentuk krim dan skim (residu gliserol). Krim (merupakan MAG, DAG, dan TAG) yang akan berada pada fase non polar, sedangkan skim (gliserol dan air) akan berada pada fase polar (Mursalin dkk., 2017a). MDAG yang merupakan emulsi air dalam minyak (w/o) akan diubah menjadi emulsi minyak dalam air (o/w) pada metode demulsifikasi krim agar creaming dapat terjadi. Pembentukan krim (creaming) dapat terjadi apabila fase terdispersi yang merupakan senyawa non polar akan terpisah ke atas akibat kerusakan emulsi (McClements, 2015). Pemisahan gliserol dari produk MDAG dengan metode tersebut dapat menurunkan kadar gliserol dari $14,66 \%$ menjadi $9,17 \%$ (tanpa penambahan larutan), 4,05-6,59\% (dengan penambahan air suling) dan $1,94-1,95 \%$ (dengan penambahan larutan elektrolit) (Mursalin dkk., 2017a).

Penggunaan larutan elektrolit sangat mempengaruhi penurunan residu gliserol pada produk MDAG. Penggunaan natrium klorida dan kalsium klorida sebagai larutan elektrolit dapat diaplikasikan pada metode demulsifikasi krim. Mursalin dkk. (2017b) menyatakan bahwa elektrolit dari kalsium klorida lebih efektif dalam menurunkan gliserol dari MDAG Fully 
Hydrogenated Palm Kernel Oil (FHPKO) hasil gliserolisis kimia, kadar gliserol yang diperoleh yaitu $0,70 \%$ lebih rendah dibandingkan dengan elektrolit dari natrium klorida yang hanya mampu menurunkan gliserol sebesar $1,64 \%$. Namun, perlu diketahui bahwa larutan dari kalsium klorida merupakan senyawa ionik yang tersusun atas molekul kalsium dan klorin, klorin/klorida baik organik maupun anorganik merupakan prekursor potensial terbentuknya senyawa 3-monochloropropane1,2-diol ester (3-MCPDE). Senyawa 3-MCPDE merupakan kontaminan yang bersifat karsinogen (non genotoxic) dan tidak volatil (Kellens dan Greyt, 2016), yang dapat terbentuk selama proses pengolahan bahan pangan ketika lemak (gliserol atau asilgliserol dan garam (ion klorida) mengalami proses pengolahan pada suhu tinggi (Larsen, 2009). Oleh sebab itu, perlu dilakukan untuk mencari larutan elektrolit lainnya yang tidak berpotensi menghasilkan 3-MCPDE, namun memiliki kemampuan yang sama seperti kalsium klorida sebagai larutan elektrolit dalam menurunkan kadar gliserol pada produk MDAG hasil gliserolisis kimia.

Kalsium nitrat dipilih sebagai larutan elektrolit untuk menggantikan elektrolit kalsium klorida pada penelitian ini. Gadzuric dkk. (2010) menyatakan bahwa kalsium nitrat tetrahidrat dan campurannya memiliki panas laten yang tinggi dan titik leleh rendah, garam ini merupakan larutan elektrolit kuat yang memiliki ion divalen $\left(\mathrm{Ca}^{2+}\right)$. Diperkirakan ion $\mathrm{Ca}^{2+}$ pada kalsium nitrat sama efektifnya dengan ion $\mathrm{Ca}^{2+}$ pada kalsium klorida untuk memecah sistem emulsi pada metode demulsifikasi krim. Hal ini yang melandasi penggunaan kalsium nitrat sebagai larutan elektrolit dalam pemurnian MDAG.

Tujuan dari penelitian ini adalah membandingkan kalsium nitrat dengan kalsium klorida sebagai larutan elektrolit dalam pemurnian MDAG dengan metode demulsifikasi krim dan mempelajari karakteristik produk MDAG yang dihasilkan.

\section{METODE PENELITIAN}

\section{Bahan}

Bahan yang digunakan terdiri dari MDAG Fully Hydrogenated Palm Kernel Oil (FHPKO) hasil gliserolisis kimia skala pilot plant yang diperoleh dari SEAFAST Center IPB (Bogor, Indonesia), Distillated Monoglyceride dari Rikevita Malaysia Sdn. Bhd. (Johor, Malaysia), rac-1Lauroylglycerol dari Sigma Aldrich (Germany), N-methyl$\mathrm{N}$-(trimethylsilyl)-trifluoroacetamide dari Sigma Aldrich (St. Louis, MO), kalsium klorida dari PT. Setia Guna (Bogor, Indonesia), kalsium nitrat tetrahydrate, tetrahydrofuran (Merck), heptana (Merck).

\section{Alat}

Peralatan proses yang digunakan antara lain satu set reaktor double jacket dengan kapasitas $1 \mathrm{~L}$ terbuat dari bahan kaca borosilikat (Duran), agitator (Overhead stirrers RW 20 digital), pemanas air (Stephan waterbath), timbangan analitik (Mettler AE 260, sartorius), hotplate stirrer (IKA tipe HS-7), sentrifugasi (Hermle Z513 centrifuge) dan infrared vortex mixer (Wizard-velp). Alat analisa yang digunakan yaituGas Chromatography (GC) dengan Flame Ionization Detector (FID) (Hewlett packard series 6890 series) dan kolom kapiler DB5 HT (30 m x 0,25 mm i.d, 0,1 $\mu \mathrm{m}$ df, Agilent, US).

\section{Metode}

\section{Pemurnian MDAG dengan Metode Demulsifikasi Krim}

Proses pemurnian MDAG dilakukan sesuai prosedur Mursalin dkk. (2017a) dengan rasio MDAG dengan larutan elektrolit yang digunakan pada pemurnian dengan metode ini adalah 1:1 (v/v). MDAG FHPKO dicairkan terlebih dahulu di dalam gelas piala hingga semua kristal mencair. MDAG yang telah cair pada penelitian ini disebut dengan crude MDAG (M1). MDAG cair (M1) bersuhu $65^{\circ} \mathrm{C}$ sebanyak $500 \mathrm{~mL}$ dimasukkan ke dalam reaktor. Larutan elektrolit dengan konsentrasi $5 \%$ sebanyak $500 \mathrm{~mL}(\mathrm{~b} / \mathrm{v})$ pada suhu di atas $10^{\circ} \mathrm{C}$ dari suhu MDAG dicampurkan ke dalam MDAG cair (M1) dan dilakukan pengadukan dengan agitator dengan kecepatan $500 \mathrm{rpm}$ selama 40 menit pada suhu $65^{\circ} \mathrm{C}$. Setelah waktu proses tercapai, campuran didiamkan selama 10 menit (pemisahan I). Fraksi krim dan skim yang diperoleh dipisahkan, fraksi skim I dikeluarkan dari reaktor. Fraksi krim I (M2) yang diperoleh selanjutnya dicuci dengan menambahkan air panas $1: 1(\mathrm{v} / \mathrm{v})$ dengan suhu $10^{\circ} \mathrm{C}$ di atas suhu krim. Selama proses pencucian dilakukan pengadukan menggunakan agitator dengan kecepatan $500 \mathrm{rpm}$ selama 10 menit pada suhu $65^{\circ} \mathrm{C}$. Setelah waktu proses pencucian tercapai, campuran didiamkan selama 10 menit (pemisahan II). Selama proses pemisahan II akan diperoleh tiga fraksi (krim, intermediate dan skim). Fraksi krim II yang telah disentrifugasi dengan kecepatan $2000 \mathrm{rpm}$ selama 5 menit disebut pure MDAG (M3).

\section{Analisis Gliserol Bebas, Asam Lemak Bebas, dan Fraksi Asilgliserol}

Analisis komposisi fraksi asilgliserol menggunakan metode modifikasi Official Method Cd 11b-91 (AOAC, 2003). Bahan baku MDAG FHPKO dan MDAG hasil pemurnian masing-masing dianalisis menggunakan GC-FID dengan kolom DB5 HT. Sampel ditimbang 
dengan teliti kurang lebih 0,0250-0,0255 g, kemudian dimasukkan ke dalam tabung vial dan ditambahkan $10 \mu \mathrm{L}$ tetrahydrofuran dan $50 \mu \mathrm{L} \quad \mathrm{N}$-methyl- $\mathrm{N}$ (trimethylsilyl)-trifluoroacetamide. Tabung vial ditutup dan divortex dengan kecepatan $2400 \mathrm{rpm}$ selama 90 detik dan dimasukkan ke dalam ruang gelap selama 10 menit. Sebanyak $2 \mathrm{~mL}$ heptan ditambahkan kemudian divortex kembali dengan kecepatan 2000 rpm selama 30 detik. Tutup bagian luar dengan parafilm. Sampel didiamkan selama 30 menit sebelum diinjeksikan, agar bereaksi terlebih dahulu. Sampel siap diinjeksikan ke dalam GC sebanyak $1 \mu \mathrm{L}$. GC yang digunakan dilengkapi dengan split injeksi atau kolom injeksi dan FID dengan operasi sebagai berikut: suhu kolom awal $50{ }^{\circ} \mathrm{C}$ dinaikkan menjadi $180{ }^{\circ} \mathrm{C}$ dengan kenaikan $15^{\circ} \mathrm{C} /$ menit kemudian dinaikkan lagi menjadi $230{ }^{\circ} \mathrm{C}$ dengan kenaikan $7{ }^{\circ} \mathrm{C} /$ menit dan dinaikkan lagi menjadi 380 ${ }^{\circ} \mathrm{C} /$ menit, suhu detektor $390{ }^{\circ} \mathrm{C}$, suhu injektor $390{ }^{\circ} \mathrm{C}$, kecepatan gas pembawa $0,7 \mathrm{~mL} \mathrm{~N} /$ /menit, kecepatan aliran udara $450 \mathrm{~mL} / \mathrm{menit}$ dan volume injeksi $1 \mu \mathrm{L}$. Hasil kromatogram dibandingkan dengan acuan referensi yang telah didapatkan pada metode AOCS berdasarkan urutan pemisahan fraksi gliserida dengan waktu retensi berbeda.

\section{Rendemen}

Nilai rendemen produk MDAG hasil pemurnian diperoleh dengan cara membandingkan volume produk yang dihasilkan dengan volume MDAG awal sebelum pemurnian dikalikan 100\% (Persamaan 1).

Rendemen $(\%)=\frac{\text { MDAG akhir }(m L)}{M D A G \text { awal }(m L)} \times 100 \%$

\section{Rancangan Penelitian}

Penelitian ini dilakukan dengan menggunakan rancangan acak lengkap satu faktor dengan tiga kali ulangan. Faktor tersebut yaitu penambahan larutan elektrolit kalsium klorida (P1) dan larutan elektrolit kalsium nitrat (P2) pada pemurnian produk MDAG FHPKO hasil gliserolisis kimia.

\section{Analisis Statistik}

Nilai yang tertera pada hasil merupakan nilai ratarata (tiga kali ulangan) standar deviasi. Data yang diperoleh pada masing-masing perlakuan diolah dengan SPSS versi 21.0 untuk analisis Uji-T (Independent sample $t$-test) pada $a=0,05$.

\section{HASIL DAN PEMBAHASAN}

\section{Pemurnian dengan Metode Demulsifikasi Krim}

Metode pemurnian demulsifikasi krim adalah metode pemecahan emulsi secara fisik (pemanasan dan pengadukan) dan secara kimia (penambahan larutan elektrolit). Pemurnian dengan metode ini terdiri dari dua

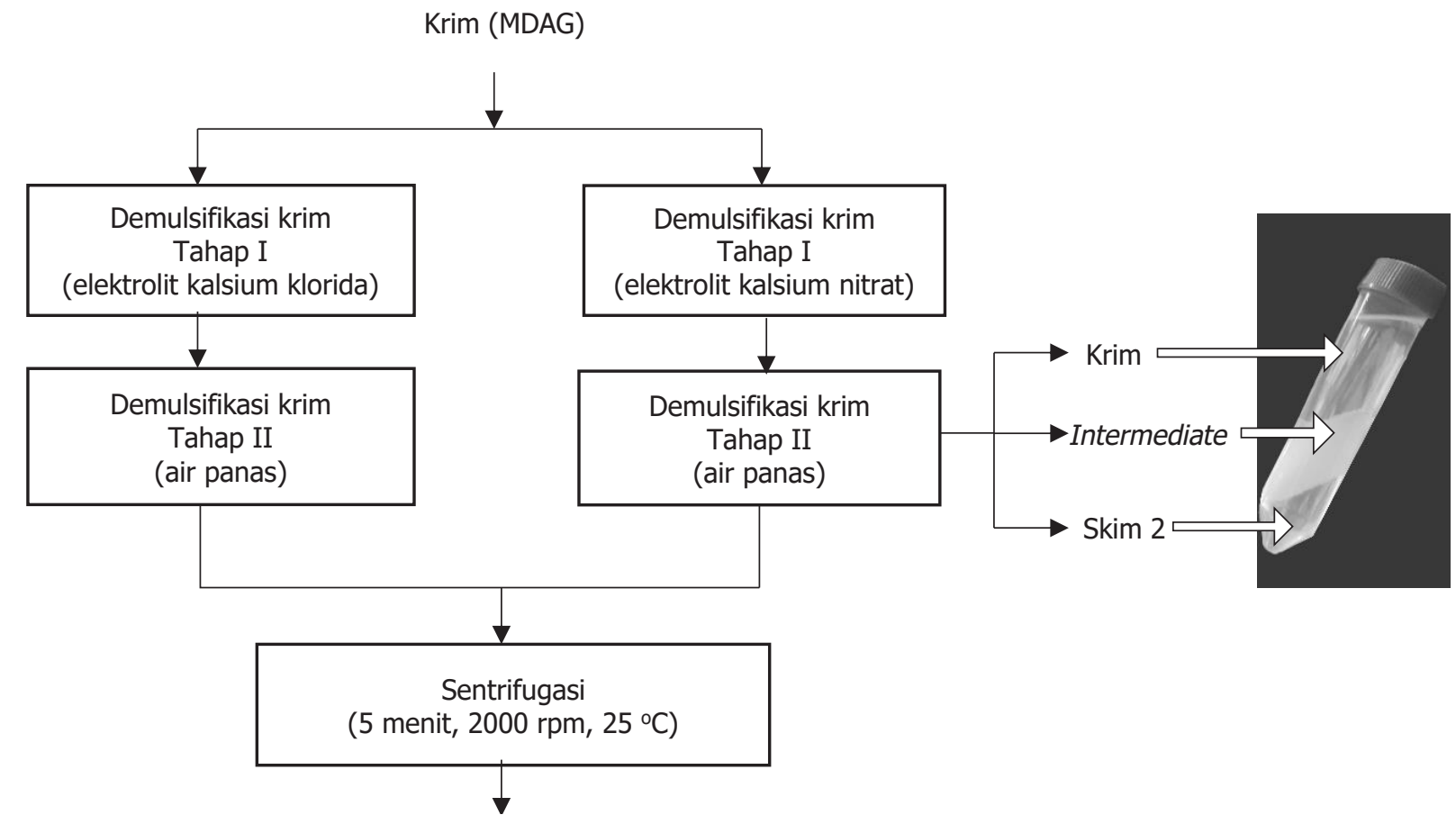

Skim 3

Gambar 1. Skema pemurnian 
tahap, yaitu pencampuran dan pemisahan. Pemurnian MDAG dengan metode ini diawali dengan pencampuran crude MDAG (cair) dalam reaktor berkapasitas $1 \mathrm{~L}$ dengan kecepatan pengadukan agitator 500 rpm. Pada saat suhu mencapai $65{ }^{\circ} \mathrm{C}$ dilakukan penambahan elektrolit (masing-masing perlakuan) suhu $10^{\circ} \mathrm{C}$ diatas suhu MDAG, kemudian pencampuran dilakukan selama 40 menit. Penerapan suhu pada metode demulsifikasi krim bertujuan untuk menurunkan viskositas campuran (Sari dan Lestari, 2015), mendestabilkan emulsi dan meningkatkan perbedaan densitas antar fase. Pengadukan juga bertujuan untuk memperkecil ukuran partikel sehingga terjadi percepatan penurunan tegangan antar muka yang diakibatkan menurunnya viskositas campuran (Sari dan Lestari, 2015). Silsia dkk. (2017) melaporkan bahwa MDAG dari CPO memiliki tegangan permukaan berada antara 26,76-34,86 dyne/cm.

Penambahan elektrolit (kalsium klorida dan kalsium nitrat) pada pemurnian dengan metode demulsifikasi krim bertujuan untuk mengubah sistem emulsi MDAG air dalam minyak (w/o) menjadi sistem emulsi minyak dalam air (o/w) sehingga pemecahan emulsi dapat terjadi dalam bentuk creaming. Creaming merupakan pemisahan antara fase yang disebabkan gaya gravitasi dan naiknya tegangan permukaan antara fase yang menyebabkan terjadi pemisahan antar fase. Kandungan gliserol yang jauh lebih sedikit dari fase non polar dengan adanya penambahan larutan elektrolit pada metode demulsifikasi krim maka gliserol dapat dipisahkan dari sistem dengan cara mengikat gliserol (fase polar) dari sistem emulsi (produk MDAG). Gliserol dan air akan berada pada fase polar (skim) dan MDAG akan berada pada fase non polar (krim) (Mursalin dkk., 2017a).

Larutan elektrolit (kalsium klorida dan kalsium nitrat) ditambahkan pada tahap pencampuran I, setelah itu dilakukan pemisahan I maka diperoleh fase non polar (krim) dan fase polar (skim). Krim (hasil pemisahan I) dilakukan penambahan air panas suhu 10 ${ }^{\circ} \mathrm{C}$ diatas suhu krim (pencampuran II), pencampuran II dilakukan selama 10 menit. Penambahan air panas pada pencampuran II bertujuan untuk mengikat sisa elektrolit dan gliserol yang terdapat pada krim (hasil pemisahan I), kemudian dilakukan pemisahan II. Hasil pemisahan II akan menyebabkan terbentuknya tiga lapisan yang tidak saling bercampur yang terdiri dari lapisan atas yaitu fase non polar (krim), lapisan tengah yaitu fase intermediate (krim dan skim) dan lapisan bawah yaitu fase polar (skim) (Gambar 1). Terjadinya fenomena ini dikarenakan perbedaan viskositas dan densitas pada fase non polar dan fase polar. MDAG pada suhu ruang berbentuk padatan dan ketika dipanaskan akan mencair (minyak). Densitas minyak pada suhu $50{ }^{\circ} \mathrm{C}$ yaitu $0,889-0,895 \mathrm{~g} / \mathrm{mL}$ (Codex, 2017), air pada suhu $50{ }^{\circ} \mathrm{C}$ memiliki densitas sebesar $0,986 \mathrm{~g} / \mathrm{mL}$ tidak jauh berbeda pada suhu $65{ }^{\circ} \mathrm{C}$ dengan nilai densitas 0,979 $\mathrm{g} / \mathrm{mL}$ (BSN, 2018). Perbedaan densitas antara MDAG dalam keadaan cair dan penambahan air panas selama proses pencampuran, setelah dilakukan pemisahan maka akan menghasilkan lapisan yang tidak bercampur karena perbedaan densitas.

Gambar 1, menunjukkan lapisan yang terbentuk setelah pemisahan II pada proses pemurnian MDAG dengan metode demulsifikasi krim. Lapisan atas merupakan fase non polar (fraksi krim yang mengandung pure MDAG), lapisan tengah merupakan fase intermediate (gabungan dari fraksi krim dan skim) dan lapisan bawah merupakan fase polar (fraksi skim yang mengandung air dan residu gliserol). Hal yang sama dilaporkan oleh Moura dkk. (2011a) dimana ekstraksi minyak dan protein dari hasil ekstruksi flakes kacang kedelai dengan metode demulsifikasi krim akan diperoleh tiga fase diantaranya fase krim yang mengandung minyak, fase skim dan fase insoluble. Fase krim yang mengandung minyak dan dilakukan demulsifikasi kimia, akan diperoleh tiga lapisan yang berbeda yaitu minyak, intermediate dan air. Fase intermediate merupakan fase yang terletak diantara minyak dan fraksi skim (Moura dkk., 2008).

Fase non polar (krim) hasil pemurnian pada kedua larutan elektrolit tidak jauh berbeda, fraksi krim yang diperoleh dari perlakuan penambahan elektrolit kalsium klorida adalah $40,57 \pm 2,50 \%$ dan elektrolit kalsium nitrat yaitu $40,17 \pm 2,39 \%$. Dari ketiga fase yang diamati, fase intermediate memiliki jumlah yang lebih rendah dibandingkan dengan fase non polar (krim) dan fase polar (skim) yaitu 15,09 $\pm 1.89 \%$ (untuk elektrolit kalsium klorida) dan 11,68 2 2,39\% (untuk elektrolit kalsium nitrat). Fase intermediate diperoleh setelah dilakukan penambahan air panas. Pada penelitian ini fase intermediate merupakan gabungan dari fraksi krim dan skim. Fraksi krim (MDAG) yang diperoleh pada fase intermediate menyatu dengan fraksi skim dikarenakan sebagian fraksi krim sedikit larut dalam air, fase ini merupakan bagian yang teremulsi (Mardaweni dkk., 2017). Chen (2015) menyatakan bahwa MDAG merupakan pengemulsi nonionik, larut dalam minyak dan sedikit larut dalam air, pada suhu tinggi (O'Brien, 2009). Setelah dilakukan sentrifugasi pada fase intermediate, didapat fraksi krim yang sangat sedikit dibandingkan fraksi skim. Hal ini sejalan dengan Moura dkk. (2008) yang menyatakan, bahwa fase intermediate merupakan lapisan krim yang tersisa akibat proses demulsifikasi. Hasil pengamatan untuk fase polar (skim) yang diperoleh, fraksi skim untuk elektrolit kalsium klorida lebih rendah 
(44,34 $\pm 0,94 \%)$ dibandingkan dengan fraksi skim untuk elektrolit kalsium nitrat $(48,15 \pm 3,84 \%)$. Perbedaan ini disebabkan masih terdapat skim di fase intermediate sehingga mempengaruhi hasil skim pada fase polar yang didapat dari kedua elektrolit setelah pemurnian.

Berdasarkan hasil pengamatan dari perbandingan persentase fase pemisahan selama proses pemurnian, fase non polar (krim) yang diperoleh dari kedua perlakuan disentrifugasi selama 5 menit dengan kecepatan 2000 rpm, sentrifugasi bertujuan untuk memisahkan gliserol (Makhtar, 2010) yang masih terdapat pada fraksi krim. Kemudian fraksi yang telah disentrifugasi (pure MDAG) dianalisis lebih lanjut kadar gliserol bebas, asam lemak bebas dan fraksi asilgliserol menggunakan instrumen GC.

\section{Kadar Gliserol Bebas}

Hasil pengukuran terhadap kadar gliserol bebas pada produk MDAG FHPKO sebelum dan setelah pemurnian dengan metode demulsifikasi krim disajikan pada Gambar 2. Bahan baku MDAG FHPKO sebelum pemurnian $(P)$ memiliki kadar gliserol bebas sebesar $11,69 \pm 0,88 \%$. Kadar gliserol bebas pada bahan baku MDAG sebelum pemurnian yang diperoleh pada penelitian ini tidak jauh berbeda dengan penelitian sebelumnya yaitu 16,44\% (Mursalin dkk., 2017a) dan 14,98\% (Mursalin dkk., 2017b). Menurut regulasi terkait pengemulsi mono-diasilgliserol, maksimal kadar gliserol bebas yang diperbolehkan adalah 7\% (Moonen dan Bas, 2004). Faergemant dan Krog (2006), juga menyatakan kadar gliserol bebas untuk MDAG komersial adalah $1-7 \%$. MDAG FHPKO sebagai bahan baku penelitian ini memiliki kadar gliserol bebas yang belum memenuhi syarat dari standar mutu dan MDAG komersial.

Gliserol bebas merupakan residu gliserol yang diperoleh dari hasil akhir produk pada reaksi gliserolisis kimia. Komponen tersebut dapat menurunkan kualitas MDAG, menurunkan sifat pengemulsi, membentuk

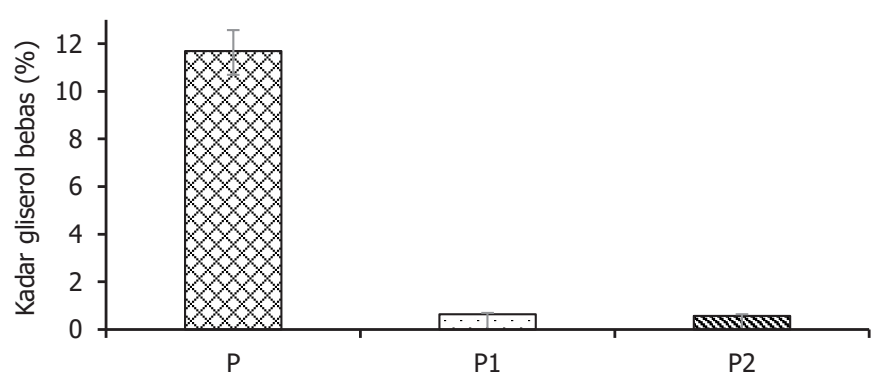

Gambar 2. Kadar gliserol bebas produk MDAG FHPKO sebelum pemurnian $(P)$, setelah pemurnian dengan perlakuan elektrolit kalsium klorida (P1) dan elektrolit kalsium nitrat (P2) tekstur berminyak, aroma yang kurang disukai konsumen, titik leleh produk menjadi rendah dan warna produk menjadi gelap dikarenakan gliserol yang terperangkap didalam produk MDAG (Setyaningsih dkk., 2016; Laksana, 2016). Oleh sebab itu, tahapan lanjutan yang diperlukan untuk memisahkan sebagian besar gliserol pada produk MDAG adalah pemurnian (Sanchez dkk., 2018).

Berdasarkan Gambar 2, perlakuan pemurnian MDAG FHPKO dengan menggunakan kalsium klorida (P1) dan kalsium nitrat (P2) sebagai elektrolit diperoleh kadar gliserol bebas sebesar 0,64 $\pm 0,06 \%$ (P1) dan $0,57 \pm 0,07 \%$ (P2). Hasil penelitian ini lebih rendah dibandingkan penelitian Mursalin dkk., (2017b) yaitu $0,70 \%$. Perbedaan ini disebabkan oleh jenis elektrolit yang digunakan dan juga kadar gliserol bebas awal pada bahan baku. Mujdalipah dkk. (2016) melaporkan pemurnian MDAG hasil gliserolisis dari bahan baku minyak sawit dengan metode ektraksi pelarut hanya dapat menurunkan kadar gliserol bebas dari 4-8\% menjadi 2,40-3,05\%. Hal ini membuktikan bahwa pemurnian dengan metode demulsifikasi krim lebih efektif dalam memurnikan MDAG hasil gliserolisis untuk menurunkan kadar gliserol bebas.

Hasil uji-T dilakukan untuk membandingkan dua data hasil pemurnian MDAG (P1) dan (P2). Kadar gliserol bebas hasil uji-T didapatkan nilai signifikan $(0,318)$, $(p>0,05)$. Hal ini menunjukkan hasil yang tidak berbeda nyata antara kadar gliserol bebas hasil pemurnian pada kedua perlakuan. Berdasarkan hasil tersebut, hal ini membuktikan bahwa penggunaan larutan elektrolit kalsium nitrat memiliki efektifitas yang sama dengan elektrolit kalsium klorida untuk memurnikan MDAG FHPKO hasil gliserolisis kimia dengan metode demulsifikasi krim.

Xia dkk. (2010), menjelaskan bahwa penambahan garam anorganik dapat memisahkan emulsi menjadi minyak dan air. Kemampuan ion dalam emulsi dipengaruhi oleh perbedaan ion atau ion terikat. Kalsium klorida dan kalsium nitrat memiliki ion $\left(\mathrm{Ca}^{2+}\right)$, kekuatan ionik pada garam anorganik dapat mempengaruhi proses demulsifikasi (Saifuddin dan Refal, 2014). Uhlig dan Wissemeier (2000) juga menyatakan bahwa kelarutan $\mathrm{Ca}\left(\mathrm{NO}_{3}\right)_{2} \cdot 4 \mathrm{H}_{2} \mathrm{O}$ pada suhu $20{ }^{\circ} \mathrm{C}$ adalah 7,74 mol/liter, sedangkan $\mathrm{CaCl}_{2} \cdot 6 \mathrm{H}_{2} \mathrm{O}$ adalah $6,71 \mathrm{~mol} / \mathrm{L}$. Penggunaan elektrolit kalsium nitrat dan kalsium klorida pada suhu yang sama yaitu $65^{\circ} \mathrm{C}$ selama proses pemurnian dengan metode demulsifikasi krim diduga memiliki kelarutan yang tidak jauh berbeda sehingga kemampuan kedua elektrolit tersebut sama efektifnya dalam menurunkan kadar gliserol bebas. Penggunaan larutan elektrolit kalsium klorida dapat menurunkan gliserol bebas dengan persentase pemisahan dari 
bahan baku sebelum pemurnian dan setelah pemurnian sebesar 95,62 $\pm 0,29 \%$ dan larutan elektrolit kalsium nitrat sebesar $96,04 \pm 0,38 \%$.

\section{Perubahan Asam Lemak Bebas dan Fraksi Asilgliserol}

Hasil analisis GC (Gambar 3), menunjukkan hasil kadar asam lemak bebas (ALB) dan fraksi asilgliserol diantaranya monoasilgliserol (MAG), diasilgliserol (DAG) dan triasilgliserol (TAG) MDAG FHPKO sebelum dan setelah pemurnian. MDAG FHPKO sebelum pemurnian

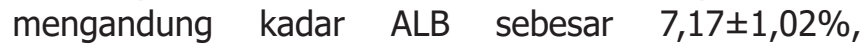
fraksi asilgliserol diantaranya kadar MAG sebesar $26,05 \pm 1,63 \%$, kadar DAG $10,81 \pm 0,44 \%$ dan kadar TAG 44,29 $\pm 2,62 \%$. Kadar ALB dan fraksi asilgliserol pada bahan baku sebelum pemurnian yang diperoleh pada penelitian ini lebih rendah dibandingkan dengan penelitian Mursalin dkk. (2017b) yaitu 7,28\% (ALB), $32,27 \%$ (MAG), 11,84\% (DAG). Namun, bahan baku MDAG FHPKO pada penelitian ini memiliki kadar TAG $(44,29 \pm 2.62 \%)$ lebih tinggi dibandingkan dengan penelitian Mursalin dkk. (2017b) yaitu 33,62\% (TAG). Hal ini disebabkan oleh komposisi TAG dan asam lemak pada bahan baku FHPKO, selama proses gliserolisis kimia tidak semua asam lemak dapat terlepas dan bereaksi dengan gliserol untuk membentuk DAG dan MAG (Triana, 2014).

Pemurnian MDAG FHPKO dengan menggunakan kalsium klorida sebagai elektrolit (P1) diperoleh kadar ALB 8,91 $\pm 0,71 \%$, kadar MAG 29,79 $\pm 1,97 \%$, kadar DAG $19,16 \pm 0,53 \%$ dan kadar TAG $41,49 \pm 3,24 \%$. Produk MDAG hasil pemurnian dengan perlakuan elektrolit

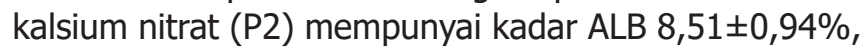

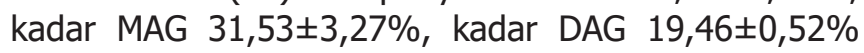

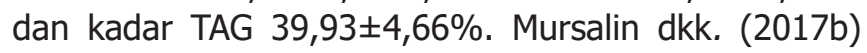
melaporkan bahwa MDAG FHPKO hasil pemurnian dengan metode demulsifikasi krim memperoleh kadar ALB sebesar 7,97\%, kadar MAG 36,24\%, kadar DAG

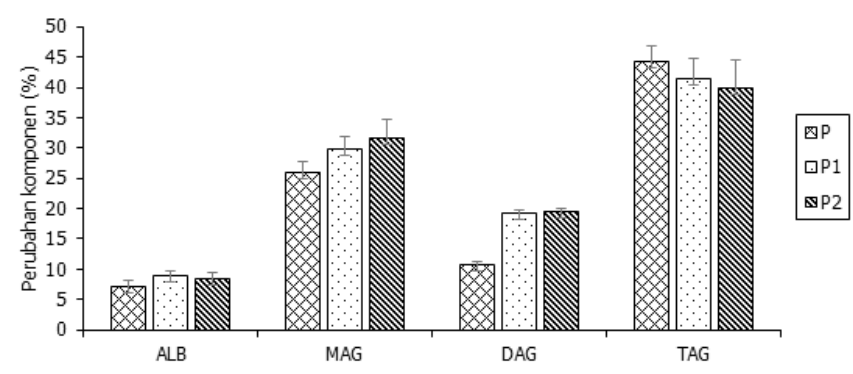

Gambar 3. Perubahan asam lemak bebas (ALB) dan fraksi asilgliserol (MAG, DAG dan TAG) bahan baku MDAG FHPKO sebelum pemurnian $(P)$ dan setelah pemurnian dengan perlakuan elektrolit kalsium klorida (P1) dan elektrolit kalsium nitrat (P2)
17,42\% dan kadar TAG 37,67\%. Persentase ALB, MAG dan DAG hasil penelitian ini lebih rendah dibandingkan penelitian Mursalin dkk. (2017b), sedangkan persentase TAG hasil penelitian ini lebih tinggi. Hal ini disebabkan karena tingginya kadar TAG pada bahan baku MDAG FHPKO sebelum pemurnian.

Berdasarkan Gambar 3, kadar ALB, MAG dan DAG hasil pemurnian dengan metode demulsifikasi krim mengalami peningkatan dari sebelum dilakukan pemurnian. Hal yang sama dilaporkan oleh Mursalin dkk. (2017b), bahwa MDAG setelah mengalami proses pemurnian dengan metode demulsifikasi krim maka komponen seperti ALB, MAG dan DAG akan meningkat. Namun pada penelitian ini terjadi penurunan untuk kadar TAG setelah pemurnian, hal ini dikarenakan adanya krim yang hilang selama proses pemurnian berlangsung. Diduga sebagian krim yang hilang mengakibatkan kadar TAG hasil pemurnian menurun.

Persentase krim yang hilang selama proses pemurnian dengan metode demulsifikasi krim diantaranya $11,33 \pm 3,06 \%$ (untuk elektrolit kalsium klorida) dan $10,33 \pm 2,89 \%$ (untuk kalsium nitrat). Persentase krim yang hilang hasil dari penelitian ini tidak jauh berbeda dengan penelitian yang telah dilaporkan oleh Moura dkk. (2011b), bahwa rata-rata kehilangan selama proses ekstraksi dengan metode demulsifikasi krim adalah $11,70 \pm 2,40 \%$. Krim yang hilang selama proses pemurnian MDAG FHPKO bisa saja disebabkan karena sebagian kecil krim masih terdapat pada fraksi skim (saat memisahkan krim dan skim), terdapat di fase intermediate, tertinggal di reaktor dan tabung centrifuge (saat dilakukan sentrifugasi). Moura dkk. (2011b) juga menyatakan bahwa minyak yang tertinggal selama proses reaksi dengan metode demulsifikasi krim terdapat di wadah centrifuge, pompa dan pipa.

Hasil Uji-T pada kedua elektrolit (kalsium klorida dan kalsium nitrat) diperoleh nilai signifikan kadar ALB $(0,361)$, MAG $(0,331)$, DAG $(0,966)$ dan TAG $(0,514)$. Nilai signifikan untuk ALB dan fraksi asilgliserol dari hasil uji-T, $(p>0,05)$ sehingga dapat diketahui bahwa tidak ada perbedaan kadar ALB dan fraksi asilgliserol yang signifikan dari perlakuan kedua elektrolit (kalsium klorida dan kalsium nitrat) hasil pemurnian MDAG dengan metode demulsifikasi krim. Namun, berdasarkan hasil analisis GC maka pemurnian dengan menggunakan elektrolit kalsium nitrat menghasilkan kadar MAG $(31,53 \pm 3,27 \%)$ lebih tinggi dibandingkan dengan kadar MAG elektrolit kalsium klorida $(29,79 \pm 1,97 \%)$. Sanchez dkk. (2018) menyatakan bahwa pemurnian dapat meningkatkan kadar MAG. Mardaweni dkk. (2017) juga melaporkan bahwa pemurnian dari bahan baku MDAG Palm Fatty Acid Distillate (PFAD) kadar MAG yang dihasilkan yaitu $31,05 \%$. 
Pada penelitian ini juga dilakukan perhitungan rendemen. Perhitungan rendemen diperoleh dengan membandingkan jumlah krim dari pure MDAG (diperoleh setelah pemurnian dan sentrifugasi) dan krim dari crude MDAG (sebelum pemurnian). Persentase rendemen krim MDAG FHPKO hasil pemurnian dengan larutan elektrolit kalsium klorida adalah sebesar $80,00 \pm 4,00 \%$ dan larutan elektrolit kalsium nitrat sebesar $81,00 \pm 3,61 \%$. Persentase rendemen krim (pure MDAG) berdasarkan hasil uji-T diperoleh nilai signifikan sebesar 1.000. Nilai signifikan untuk nilai rendemen dari hasil uji-T $(p>0,05)$ sehingga dapat diketahui bahwa tidak ada perbedaan nilai rendemen yang signifikan dari kedua elektrolit (kalsium klorida dan kalsium nitrat) hasil pemurnian MDAG dengan metode demulsifikasi krim. Hasil persentase rendemen pada penelitian ini tidak jauh berbeda seperti yang telah dilaporkan oleh Moura dkk. (2011a) yaitu persentase rendemen yang akan dihasilkan dengan metode demulsifikasi krim berkisar antara $76-95 \%$.

\section{KESIMPULAN}

Berdasarkan penelitian yang telah dilakukan, dapat disimpulkan bahwa kalsium nitrat dapat digunakan untuk menggantikan kalsium klorida sebagai larutan elektrolit dalam memurnikan MDAG hasil gliserolisis kimia dengan metode demulsifikasi krim. Penggunaan kalsium nitrat sebagai larutan elektrolit memiliki karakteristik yang tidak berbeda dengan larutan elektrolit kalsium klorida berdasarkan Uji-T terutama dalam menurunkan residu gliserol pada produk MDAG.

\section{UCAPAN TERIMA KASIH}

Penulis mengucapkan terima kasih kepada Southeast Asian Food and Agricultural Science and Technology (SEAFAST) Center IPB yang telah memberikan dana riset dan fasilitas penelitian.

\section{KONFLIK KEPENTINGAN}

Tidak ada konflik kepentingan dalam penelitian ini.

\section{DAFTAR PUSTAKA}

Agustina, L. C. (2019). Perubahan Komposisi Fraksi Asilgliserol selama Sintesis Mono-Diasilgliserol dari Stearin Sawit dengan Metode Gliserolisis Skala Pilot Plant. Bogor: Institut Pertanian Bogor.

AOAC. (2003). Association of official analytical chemist. Official methods of analysis. Washington DC (US), AOAC International.
BSN. (2018). Badan Standardisasi Nasional. ISO 6883:2017 Animal and Vegetable Fats and Oils - Determination of Conventional Mass per Volume (Litre Weight in Air), Jakarta.

Chen, L. (2015). Emulsifiers as Food Texture Modifiers. Modifying Food Texture, (pp 27-49).

Codex. (2017). Codex Allimentarius. CODEX STAN 210-1999. Codex Standard for Names Vegetable Oils, Roma.

Faergemant, M. \& Krog, N., (2006). Interactions of Emulsifiers with Other Components in Foods. In Ingredient Interactions Effects on Food Quality (2nd ed.). (pp. 389419).

Gadzuric, S., Vranes, M., \& Dozic, S., (2010). Electrical Conductivity and Phase Transitions of Calcium Nitrate + Ammonium Nitrate + Water Mixtures. Journal of Chemical and Engineering Data. 55: 1990-1993.

Kellens, M., \& Greyt, WD., (2016). 3-MCPD and GE. A New Challenge. https//www.omagazine.com [Agustus 2018].

Laksana, AJ. (2016). Penggandaan Skala Produksi Mono dan Diasilgliserol (MDAG) Berbasis Sawit dengan Metode Gliserolisis. Institut Pertanian Bogor.

Larsen, JC., (2009). ILSI Europe Report Series: 3-MCPD Ester in Food Products. Int Life Sci Inst.

Mardaweni, R., Setyaningsih, D., \& Rusli, MS., (2017). Pemurnian Mono-Diasilgliserol Hasil Esterifikasi Palm Fatty Acid Distillate dan Gliserol dengan Ekstraksi Pelarut-Saponifikasi dan Distilasi Molekuler. Jurnal Teknologi Industri Pertanian, 27(2): 192-199.

McClements, DJ., (2015). Food Emulsions Principles, Practices and Techniques (3rd ed.) CRC Press.

Makhtar, NA., (2010). Effect of PH and Glycerol Waste Amount on the Glycerol Recovery. University Malaysia Pahang.

Moonen, H., \& Bas, H., (2004). Mono-and Dyglycerides: Emulsifiers in Food Technology. (Whitehurst RJ, ed). Oxford (GB): Blackwell Scientific.

Moonen, H., \& Bas, H., (2015). Mono and Diglycerides. In Emulsifiers in Food Technology. John Wiley \& Sons, Ltd. UK.

Moura, JMLN., Campbel, K., Mahfuz, A., Jung, S., Glatz, CE., \& Johnson, L., (2008). Enzyme-Assisted Aqueous Extraction of Oil and Protein from Soybeans and Cream De-emulsification. Journal of the American Oil Chemist Society, 85: 985-995. http://doi.org/10.1007/s11746008-1282-2.

Moura, JMLN., Mourer, D., Jung, S., \& Johnson, LA., (2011a). Integrated Countercurrent Two-Stage Extraction and Cream Demulsification in Enzyme-Assisted Aqueous Extraction of Soybeans. Journal of the American Oil Chemist Society, 88: 1045-1051. http://doi.org/10.1007/ s11746-011-1759-2. 
Moura, JMLN., Mourer, D., Jung, S., \& Johnson, LA., (2011b). Pilot-Plant Proof-of-Concept for Integrated, Countercurrent, Two-Stage, Enzyme-Assisted Aqueous Extraction of Soybeans. Journal of the American Oil Chemist Society, 88: 1649-1658. http://doi.org/10.1007/ s11746-011-1831-y.

Mujdalipah, S., Sasmita, AH., Amalia, IK., \& Suryani, A., (2016). Separatiom of Glycerolysis Product Using Hexane. International Conference on Innovation in Engineering and Vocational Education, 128.

Mursalin., Lavlinesia., \& Yernisa., (2017a). Aplikasi Teknik Demulsifikasi Pembentukan Krim dalam Pemurnian MDAG yang Diproduksi Secara Gliserolisis. Jurnal Ilmiah IImu Terapan Universitas Jambi, 1(2):170-177.

Mursalin., Sahrial.,\& Wulandari, N., (2017b). Efektivitas $\mathrm{NaCl}$ dan $\mathrm{CaCl}_{2}$ dalam Memurnikan MDAG dengan Metode Creaming Demulsification Technique. Prosiding Seminar Nasional FKPT-TPI 2017. Kendari, Indonesia.

O'Brien, RD., (2009). Fats and Oils: Formulating and Processing for Applications, Florida (USA). CRC Press.

Rachmawati, D. (2017). Sintesis Mono-Diasilgliserol dari Refined Bleached Deodorized Palm Oildengan Metode Gliserolisis Skala Laboratorium. Institut Pertanian Bogor.

Rarokar, NR., Menghani, S., Kerzare, D., \& Khedekar, PB., (2017). Progress in Synthesis of Monoglycerides for Use in Food and Pharmaceuticals. Journal of Food and Pharmaceutical Sciences, 2472-0542.

Rossi, P., Grosso, NR., Pramparo, MC., \& Nepote, V., (2012). Fraction and Concentration of Omega-3 by Molecular Distillation. Eicosapentaenoic Acid: Sources Health Effects and Role in Disease Prevention, 177-203.

Rumondang, I., Setyaningsih, D., \& Hermanda, A., (2016). Sintesis Mono-Diasilgliserol Berbasis Gliserol dan Palm Fatty Acid Distillate. Jurnal Kimia dan Kemasan, 38(1) : 1-6.
Saifuddin, N., \& Refal, H., (2014). Separation of Water From very Stable Water-in-Oil Emulsions Using Microwave Radiation with Presence of Inorganic Salts. International Journal of Chemistry, 35(1): 1512-1521.

Sanchez, E., Castano, CP., \& Bolanos, G., (2018). Purification of Monoglycerides from Palm Stearin by Liquid-Liquid Extraction with Aqueous Ethanol. Journal of the American Oil Chemist Society, 95: 217-228.

Sari, DK., \& Lestari, RSD., (2015). Pengaruh Waktu dan Kecepatan Pengadukan terhadap Emulsi Minyak Biji Matahari (Helianthus annuus L.) dan Air. Jurnal Integrasi Proses, 5(3): 155-159.

Setyaningsih, D., Bashir, BA., Silalahi, VHY., Muna, N., (2016). Purification of Mono-Diacylglycerol Through Saponification and Solvent Extraction. International Journal Environment and Bioenergy, 11(1) : 1-11.

Silsia, D., Surawan, FED., Meiriska, I., (2017). Karakteristik Emulsifier Mono dan Diasilgliserol (MDAG) dari Crude Palm Oil (CPO) yang Berasal dari Fat Pit in Various Concentration of $\mathrm{NaOH}$ Catalyst. Jurnal Teknologi dan Industri Pertanian Indonesia, 9(2): 82-88.

Triana, RN. (2014). Sintesis Mono dan Diasilgliserol (MDAG) dari Fully Hydrogenated Palm Kernel Oil (FHPKO) dengan Metode Gliserolisis. Institut Pertanian Bogor.

Uhlig, BA., \& Wissemeier, AH., (2000). Reduction of NonIonic Surfactant Phytotoxicity by Divalent Cations. Crop Protection, 19: 13-19.

Xia, L., Ying, XG., \& Wei, S., (2010). Salt-Assisted Microwave Demulsification. Lianing University. Taylor and Francis Inc, China.

Zhang, Z., Ma, X., Wang, Y., Yan, R., \& Liu, M., (2014). Production of Monoacylglycerols from Fully Hydrogenated Palm Oil Catalyzed by Hydrotalcite Loaded with $\mathrm{K}_{2} \mathrm{CO}_{3}$. Chemical Engineering Communications, http://doi.org/10.1080/0 0986445.2013 .853294$. 